Volume 7 Issue 2, June 2020

Nationally Accredited Journal,

Decree No. B/4130/E5/E5.2.1/2019

\title{
Review Of The Implementation Process Of Completion Of Juridical Code Violations Of Notary In Kendari
}

\begin{abstract}
Hendro Kusuma Jaya ${ }^{1}$ and Amin Purnawan²
Abstract. Purposethis research are: 1)To identify and analyze judicial review implementation of the resolution process code violations notary in Kendari. 2) To identify and analyze the barriers and solutions implementation settlement process code violations notary in Kendari.The method used by researchers isempirical approach juridical law and specification in this study were included descriptive analysis. As for sources and types of data in this study are primary data obtained from field studies with interviews with the Honorary Board and Notary in Kendari. And secondary data obtained from the study of literature. Based on the results of research that Judicial review implementation of Resolution Process Notary Code Violations In Kendari is a sanction that can be imposed by the Council of Honor of the Notary who proved to have violated the code of conduct in the form of a notary deed outside the office is layoffs. Obstacles in the process of settlement of violations of the code of ethics Notary in Kendari that the number of notaries who are numerous, with wide working area, the lack of awareness of the Notary to abide by a code of ethics, and supplies obtained Notary is not enough for his education, and still overlapping control regulations code conduct between the Honorary Board and the Supervisory Council of Notaries. Meanwhile, the Assembly secretariat Supervisory namely the unavailability of a representative, a lack of budgetary funds to conduct surveillance and optimal development, lack of attention / concern of government, and the lack of moral / Notary in running UUJN behavior and Notary Code. To provide a solution for the finalization of code violations Notary in Kendari, namely to provide guidance, supervision, guidance and counseling.

Keywords : Judicial Review; Settlement; Breach; The Code; Notary.
\end{abstract}

\section{Introduction}

Traveling notary Indonesia experienced several developments in accordance with the development of the State and the nation of Indonesia. Contemporary history of Indonesia noted that in the era of reform changes significantly notary institution. The changes are marked by the success of the Reform Order government enacted Law No. 30 of 2004 concerning Notary (UUJN). UUJN a substitute for regulation.

Notary institution is one of the social institutions that exist in Indonesia. This institution arising from the needs of society requires an evidence of the relationship existing civil law and will occur between them. Given the increasing needs of the community and will Notary services Notary then formed specifically to serve the public in the field of civil, especially in making authentic act as it turns out in article 1868 of the Civil Code, namely: "Authentic deed is a deed in the form prescribed by law, be made by or before public officials in power to it at the place where the deed made." ${ }^{3}$

Indonesia as a state of law, as contained in Article 1 (3) of the Constitution of the Republic of Indonesia, 1945. Then all aspects of life in society to be unfounded and

1 Student Master of Notary Program, Faculty of Law, Sultan Agung Islamic University, Semarang, email: hendroaja.hj@gmail.com

${ }^{2}$ Faculty of law, Universitas Islam Sultan Agung

3 Subekti and R. Tjitrosudibio, 1996, Kitab Undang-Undang Hukum Perdata[Burgerlijk Wetboek], translated by Pradnya Paramita, Jakarta, p. 1868 
should not deviate from the norms of law in Indonesia. Related to this the notary institution in civil relationships involving an authentic deed must be made by a Notary Public.

Notary has a very important role in the traffic law, particularly in the areas of civil law, because the notary serves as a public official, which has the authority to make an authentic deed and other authorities. ${ }^{4}$

In a Notary Public Ethics code Article No 5, which among other things about the personality of a Notary, the Notary in their duties, notary with clients, notary with peers and the latter about supervision.Notaris as public officials in carrying out its duties imbued Pancasila, conscious and obey the laws and good personality and uphold the dignity and honor of the Notary (Notary Code Article 1).

Furthermore, according to the provisions of Article 2 Notary Code explains that: "Notary in carrying out his obligations aware of his own work, honestly and impartially, with a full sense of responsibility, do not hold a branch office, and not to use intermediaries as well as the use of mass media promotional nature. Providing services to people who need his service with give the best counseling law as well as providing services to the poor for free ".

According to Munir Fuady position of a code of conduct for notaries is important, first, not only because the notary is a profession that needs to be governed by a code of ethics, but also because of the nature and essence of the work of notaries who strongly oriented towards legalization, so that it can be fundamental to the main law on status of property, rights and obligations of the clients who use the services of a notary. Second, to prevent injustice as a result of granting the status of property, rights and obligations that are not in accordance with the rules and principles of law and justice, so as to disrupt public order and also interferes with individual rights of people seeking justice, then the world indispensable notary also a good professional ethics and modern. ${ }^{5}$

Position carried Notary is a position of trust that is mandated by law and society, for which a Notary is responsible for carrying out the trust given to him with always uphold the ethics of law and the dignity and nobility of his position, because if it is passed by a Notary Public, will dangerous for the general public it serves. In his execute Notary must comply with all the advantage live and thrive in society. Aside from the responsibilities of the ethics of the profession, their integrity and morals are essential requirements that must be owned by a Notary Public. Morals are morals, manners associated with poorly received good overview of the actions, attitudes, and liabilities. ${ }^{6}$

Notary as a profession is the main basis of trust and notary bear a heavy mandate for the trust given by the people to him. Value is more than a profession is as far as whether a professional is able to resist the temptation to distort the confidence entrusted to them, but the temptation to misappropriate trust so great foundation in the form of morality is an absolute to be built Notary as a group on board, has a large contribution to the wider community in build morality. ${ }^{7}$

In line with the development of information and communication technology would also

\footnotetext{
${ }^{4}$ Salim, HS, 2015. Teknik Pembuatan Akta Satu Konsep Teoritis, Kewenangan Notaris, Bentuk dan Minuta Akta, Raja Grafindo Persada, Jakarta, p.33

${ }^{5}$ Munir Fuady 2005, Profesi Mulia (Etika Profesi Hukum bagi Hakim, Jaksa, Advokat, Notaris, Kurator dan Pengurus, Citra Aditya Bakti, Bandung, p 133.

${ }^{6}$ Anke Dwi Saputro (ed), 2008, Jati Diri Notaris Indonesia dulu, sekarang dan masa mendatang, (Central Board Indonesian Notary Association), hal.193.

${ }^{7}$ Abdul Ghofur Anshori, 2009, Lembaga Kenotariatan Indonesia, UII Press, Yogjakarta, p. 1
} 
Volume 7 Issue 2, June 2020

Nationally Accredited Journal,

Decree No. B/4130/E5/E5.2.1/2019

give a big impact to the notary in Indonesia. The purpose utilization of information and communication technology is one of them is to improve the effectiveness and efficiency of public services. Utilization has become an important part especially for the capacity of the legal profession, especially for notary public in carrying out the functions and positions as public officials, among others, be used for the dissemination of legal documentation, legal information, even to solve a legal problem related to the profession of notary, the interests of justice and certainty law. ${ }^{8}$

Based on the above the author intends to conduct research with the aim: To identify and analyze completion violation judicial review process execution code of conduct notary in Kendari; and to identify and analyze the barriers and solutions implementation settlement process code violations notary in Kendari.

\section{Research methods}

The method used by researchers isempirical approach juridical law and specification in this study were included descriptive analysis. The source and type of data in this study are primary data obtained from a field study with interviews of the Honorary Board of Notaries Region and Southeast Sulawesi Regional Supervisory Council of Notaries of Kendari. And secondary data obtained from the study of literature.

\section{Results and Discussion}

\subsection{Judicial review implementation of Resolution Process Notary Code Violations in Kendari}

Notary Code entire moral code is determined by the "Society", which apply and must be adhered to by all members of the "Society" and others who assumed office Notary office both in execution and in everyday life. Notary really need to know and understand the Code, regulate any actions can be considered as a violation of the Code of Conduct and sanctions when violated the Code of Conduct. The existence of Notary Code is the logical consequence of a job Notary profession. There was even a suggestion that the Notary as a public official entrusted must hold not only on laws and regulations alone, but also on the Code of Conduct profession because of the absence of the Code, ${ }^{9}$

There is an opinion stating that the Notary as a public official to carry out the trust must adhere not only to the rules Invite Regulations alone, but also on the Code of Conduct profession, because without their Code of Conduct profession the dignity of the profession will vanish. As for Notary differentiate responsibilities be four kinds: ${ }^{10}$

- Notary civilly liable to the material truth of the deed he had made;

- Notary criminally responsibility of the authenticity of the material in the deed he had made;

- Responsibilities of the Notary Notary Regulation against the material truth in deed he had made;

- Notary responsibility of duty office by a Notary Code.

\footnotetext{
${ }^{8}$ Indonesia Legal Center Publishing, 2014, Suplemen Jabatan Notaris, Indonesia Legal Center Publishing, Jakarta, p. 2.

${ }^{9}$ Abdul Gh ofur An sh or i, 2009, op.cit, p al. 48.

10 Nico, 2003, Tanggungjawab Notaris Selaku Pejabat Umum, Center for Documentation andStudies of Business Law (CDbl), Yogyakarta, p. 8.
} 
Law serves as the protection of human interests. To be human interests are protected, the law should be executed, law enforcement can take place as normal, peaceful, but it can occur also because of violations have been breached law. Which it should be enforced. Through the enforcement of this law becomes a reality. Law enforcement, there are three elements that must be considered, namely: Legal Certainty (Rechts Sicherheit), usefulness (Zweckmassigkeit) and justice (Gerechtigkeit). ${ }^{11}$

Based on the interview with the Secretary of the Regional Committee of the Honorary Board Notary Region Southeast Sulawesi, Siti Nur Farha Tane., SH., M. $\mathrm{Kn}^{12}$ declare that the Notary Code Violations were from a report by fellow Notaries, the report of the Society and based on the findings of the Honorary Council of Regions.

Honorary Board is authorized to conduct examination of a violation of the code of conduct and sanctions against violators in accordance with the authority and duty to:

- do the coaching, guidance, supervision, reform member of upholding the code of ethics;

- examine and take a decision on the alleged violation of the code of conduct that is internal or who do not have the community participates directly;

- provides advice and opinions to the supervisory council of the alleged violations of ethics codes and notary office.

Honorary Board consists of: On the first level by the Regional Ethics Board; On appeal by the Regional Ethics Board; At the last level by the Honorary Board of the Center. ${ }^{13}$

The process of settlement of violations of the code of conduct notary in Kendari is unprofessional Notaries often ignore statutory act ethics code profession because some of the most fundamental reason either as individual members of the public as well as labor relations in professional organizations in addition to human nature which consumerism and the value of fee for services not comparable to the services provided, on the basis of those factors, it can be inventoried fundamental reasons why professionals tend to ignore and even branched code of conduct, among others: ${ }^{14}$ Influence of Kinship properties; Effect of Position; Influence of Consumerism; and Because Weak Faith.

A violation of the code of conduct does not necessarily directly sanctioned. Should an inspection for the violation. In accordance with the Notary Code, the process of resolving an ethical violation as follows:

- Supervision (Article 7)

- At the district / city level by the Regional Board and the Regional Ethics Board.

- At the provincial level by the Regional Board and the Regional Ethics Board.

- At the national level by the Central Board and the Honorary Board of the Center.

- Facts Alleged Violation (Article 8)

Honor Council fact-finding on the alleged violations of the Code by members of the association on its own initiative or on a complaint in writing from members of the association.

- Inspection and imposition of sanctions (Article 9)

- Honorary Board after finding the facts violations of the code of conduct, at least 14 days should call a member of the allegedly infringing. If not present called

\footnotetext{
${ }^{11}$ Soedikno Mertokusumo, 1999, Mengenal Hukum Suatu Pengantar, Liberty, Yogyakarta, p. 145

12 Results Interview with Siti Nur Farha Tane., SH., M.Kn, Notary Honorary Secretary of the Board Regional Committee Regional Southeast Sulawesi, on December 23, 2019, 11:00 pm

${ }^{13}$ Results Interview with Siti Nur Farha Tane., SH., M.Kn, Notary Honorary Secretary of the Board Regional Committee Regional Southeast Sulawesi, on December 23, 2019, 11:00 pm

${ }^{14}$ Mohammed Abdulkadir, 2001, Etika Profesi Hukum, Citra Aditya Bakti, Jakarta, .It. 83-84.
} 
Volume 7 Issue 2, June 2020

Nationally Accredited Journal,

Decree No. B/4130/E5/E5.2.1/2019

back 14 days, until the call is three.

- If until the third call was not present Honorary Council will remain in session and the decision making process in the form of sanctions.

- If they are not convicted of violations, then the member is restored to its name with the Decree of the Honorary Board of the check.

- Inspection and Imposition of Sanctions On Appellate (10)

- Proposed maximum of 30 days after receipt of the Decree sanctioning of the Honorary Board.

- Submitted in writing to the Council of Honor

So the sanctions that can be imposed by the Council of Honor of the Notary who proved to have violated the code of conduct in the form of a notary deed outside the office is layoffs.

\subsection{Barriers and Solutions Process Executions Notary Code Violations in Kendari}

Based on the Decree of Ministry of Justice of Republic of Indonesia on January 23, 1995 Number C2-1011.HT.01.06 1995, and was published in the Official Gazette of the Republic of Indonesia on April 7, 1995 No. 28, Supplement No. 1 / P-1995, therefore as an organization and Notaries referred to in UUJN No. 30 of 2004 concerning Notary who invitation in State Gazette 2004 No. 117. According to Article 1 paragraph (5) UUJN, said that the organization of the notary is a professional organization of office Notary formed associations with legal status.

Carry out the duties of office of a Notary must cling to the office of the Notary Code. The code of conduct is guidance, counseling, morals or decency guidelines for a particular profession or a list of obligations in running a profession drawn up by members of the profession itself damn tie them in practise. Thus the Notary Code of Conduct is the guidance, counseling, morals or decency guidelines Notary well as private and public officials appointed by the government in order to provide services to the general public, especially in the field of deed. ${ }^{15}$

The discussion of the code of conduct can not be separated from Notary Law No. 30 of 2004. In Notary ethical code consists of obligations, prohibitions and sanctions and law enforcement for the purpose of the establishment of a code of conduct and Law Notary may walk orderly.

Based on interviews with Sudirman, SH., M.Kn, as members of the Regional Supervisory Council of Notaries of Kendari in conducting law enforcement there are several obstacles faced by the Notary in Kendari, namely: ${ }^{16}$

Currently the number of Notaries has been more and more, while the Regional Ethics Board amounted to only 3 (three) members and is collective, so if there are absent because of the rush or other obstacles that can not Notary official duty optimally. With many Notaries and ample work area, then the WCA Board of Regional difficult to carry out supervision and oversight of the code of conduct to all Notary well as desired in the code of conduct. In addition, the low awareness of the Notary to obey the code of conduct, this happens because the education is based on the theory of Notaries for

15 Liliana Tedjosaputro, 1995, Elika Profesi Notaris Dalam Penegakan Hukum Pidana, Bigraf Publishing, Yogyakarta. 29 things

${ }^{16}$ Results of interviews with Sudirman, SH., M.Kn, as members of the Supervisory Council of Regions Notary Kendari, on December 26, 2019, 10:45 AM PST 
Notary profession as a practice, so a lot of Notaries to make mistakes which is a violation of professional ethics.

Related enforcement Notary Code, then Ira Koesoemawati and Yunirman Rijan found: ${ }^{17}$ Although these codes are made with a firm and clear and formed turns in the field is still a lot of violations. Start of violations that occur because of ignorance will Notary code of ethics to violations that occur because of "pretending not to know" or even some that are not concerned with the existence of a code of ethics Notary. The violations occurred may arise due to various factors, such as factor surveillance carried out internally by the board of trustees are not effective. It happened because that oversees the notary is a "fellow Notaries own" resulting in less effect of authority on the Notary, although honorary board members are senior Notary Public Notary.

The application of sanctions is essential in order to realize the professionalism, therefore when sanctions that already exist and have contributed greatly to the increased professionalism Notary, then it should have the additional sanctions that the adoption of which must also especially previously agreed by fellow Notary ie penalties, since penalties would also give direct effect when one of the violations related to a Notary Public Notary Code. ${ }^{18}$

Based on interviews with Sudirman, SH., M.Kn, in providing solutions Notary Code violations in Kendari, namely: ${ }^{19}$ Basically the code violations, the internal nature or not linked directly to the interests society. In take steps to prevent it always guidance and supervision including providing guidance to all Notary through discussion, sharing, and through seminars at events held by local officials. Against that breach the code of conduct it seeks to provide direction and guidance so as never again to do that, and to the more serious offenses will give severe punishment to make a proposal to the Regional Committee.

\section{Closing}

\subsection{Conclusion}

- Judicial review implementation of Resolution Process Notary Code Violations In Kendari

So the sanctions that can be imposed by the Council of Honor of the Notary who proved to have violated the code of conduct in the form of a notary deed outside his territory is temporary dismissal

- Barriers and Resolution Process Solutions Notary Code Violations in Kendari Obstacles in the process of settlement of violations of the code of ethics Notary in Kendari that the number of notaries who are numerous, with wide working area, the lack of awareness of the Notary to abide by a code of ethics, and supplies obtained Notary is not enough for his education, and still overlapping control regulations code conduct between the Honorary Board and the Supervisory Council of Notaries. Meanwhile, the Assembly secretariat Supervisory namely the unavailability of a representative, a lack of budgetary funds to conduct surveillance and optimal development, lack of attention / concern of government, and the lack of moral / Notary in running UUJN behavior and Notary Code.

${ }^{17}$ Ira Koesoemawati and Yunirman Rijan 2009, Ke Notaris, Raih Asa Sukses, Jakarta, p. 54-55.

18 Syihan et.al, pelaksanaan Kode Etik Dalam Menjalankan Jabatan Notaris, pasca.unhas.ac.id/journal/files

${ }^{19}$ Results of interviews with Sudirman, SH., M.Kn, as members of the Supervisory Council of Regions Notary Kendari, on December 26, 2019, 10:45 AM PST 
Volume 7 Issue 2, June 2020

Nationally Accredited Journal,

Decree No. B/4130/E5/E5.2.1/2019

To provide a solution for the finalization of code violations Notary in Kendari, namely to provide guidance, supervision, guidance and counseling. Included in providing strict sanctions as part of coaching. Carry out awards (reward) and punishment (punishment) to the Notary in implementing the Notary Code provisions.

\subsection{Suggestion}

- For Notary in order to run suitable profession with the demands of the professional ethics, a notary must have three moral characteristics, namely: Must be a person who is not diverted from its determination by all kinds of feelings of fear, lazy, shy, emotional, and so forth. That means he must have a strong moral personality; Should radar that maintains the demands of professional ethics is a serious obligation; Must have enough idealism.

- Improve infrastructure and facilities to support operational performance. Obviously in this case must be provided adequate budget, therefore the Minister as a Notary Supervisory naturally an appropriate defense budget to support the efforts of the coaching, counseling and supervision by the Supervisory Council of Notaries and Honorary Council. For those who will run the office of Notary Public Notary should be professional, honest, trustworthy, independent, responsible and have high dedication and loyalty will be the profession. Notaries also should honor and respect your colleagues, clients or the public at large as well as serving the nation and the country, and uphold the dignity of the profession and comply with the legislation in force. To be able to perform preventive and curative efforts in terms of preventing violations Notary Code, it would require the Notary Supervisory Council and the Council of Honor solid, tough and brave to enforce norms and moral values contained in the Notary Code consistently and indiscriminately. Notary Supervisory Council and the Board of Ethics should also be pro-active in finding violations that happen, not waiting for any report. As well as having knowledge about the world of notaries and integrity. Coaching and socialization Notary Code continuous effort should still be prioritized by the Supervisory Council of Notaries and Honorary Council. tough and brave to enforce norms and moral values contained in the Notary Code consistently and indiscriminately. Notary Supervisory Council and the Board of Ethics should also be pro-active in finding violations that happen, not waiting for any report. As well as having knowledge about the world of notaries and integrity. Coaching and socialization Notary Code continuous effort should still be prioritized by the Supervisory Council of Notaries and Honorary Council. tough and brave to enforce norms and moral values contained in the Notary Code consistently and indiscriminately. Notary Supervisory Council and the Board of Ethics should also be pro-active in finding violations that happen, not waiting for any report. As well as having knowledge about the world of notaries and integrity. Coaching and socialization Notary Code continuous effort should still be prioritized by the Supervisory Council of Notaries and Honorary Council. As well as having knowledge about the world of notaries and integrity. Coaching and socialization Notary Code continuous effort should still be prioritized by the Supervisory Council of Notaries and Honorary Council. As well as having knowledge about the world of notaries and integrity. Coaching and socialization Notary Code continuous effort should still be prioritized by the Supervisory Council of Notaries and Honorary Council. 


\section{References}

[1] Abdul Ghofur Anshori, 2009, Lembaga Kenotariatan Indonesia, UII Press, Yogjakarta

[2] Anke Dwi Saputro (ed), 2008, Jati Diri Notaris Indonesia dulu, sekarang dan masa mendatang, (Central Board Indonesian Notary Association),

[3] Indonesia Legal Center Publishing, 2014, Suplemen Jabatan Notaris, Indonesia Legal Center Publishing, Jakarta

[4] Ira Koesoemawati and Yunirman Rijan 2009, Ke Notaris, Raih Asa Sukses, Jakarta

[5] Liliana Tedjosaputro, 1995, Elika Profesi Notaris Dalam Penegakan Hukum Pidana, Bigraf Publishing, Yogyakarta

[6] Mohammed Abdulkadir, 2001, Etika Profesi Hukum, Citra Aditya Bakti, Jakarta

[7] Munir Fuady 2005, Profesi Mulia (Etika Profesi Hukum bagi Hakim, Jaksa, Advokat, Notaris, Kurator dan Pengurus), Citra Aditya Bakti, Bandung

[8] Nico, 2003, Tanggungjawab Notaris Selaku Pejabat Umum, Center for Documentation and Studies of Business Law (CDBL), Yogyakarta

[9] Salim, HS, 2015. Teknik Pembuatan Akta Satu Konsep Teoritis, Kewenangan Notaris, Bentuk dan Minuta Akta, Raja Grafindo Persada, Jakarta

[10]Soedikno Mertokusumo, 1999, Mengenal Hukum Suatu Pengantar, Liberty, Yogyakarta

[11]Subekti and R. Tjitrosudibio, 1996, Kitab Undang-Undang Hukum Perdata[Burgerlijk Wetboek], translated by Pradnya Paramita, Jakarta, Ps. 1868

[12]Syihan et.al, the implementation of the Code of Ethics in Running JabatanNotaris, pasca.unhas.ac.id/journal/files 